\title{
DETERMINATION OF SURFACE WATER QUALITY BASED ON MACROZOOBENTHOS BIODIVERSITY AND THE PREVALENCE OF TREMATODES CERCARIAE IN FRESHWATER MOLLUSCS
}

\author{
SITI MUYASAROH ${ }^{1,2^{*}}$ and BARTI SETIANI MUNTALIF ${ }^{1}$ \\ ${ }^{1}$ Department of Environmental Engineering, Faculty of Civil and Environmental Engineering, \\ Institut Teknologi Bandung, Jl. Ganesha No.10 Bandung 40132, Indonesia \\ ${ }^{2}$ Department of Biology Education, Faculty of Mathematic and Natural Science, \\ IKIP PGRI Jember, Jl. Jawa No. 10 Jember 68121, Indonesia \\ *E-mail: muyassaroh.siti@yahoo.co.id
}

Accepted 30 April 2020, Published online 6 July 2020

\begin{abstract}
Lake Cisanti is the upstream of Citarum River and silting has occurred in the inlet areas. This water body was selected as the research area due to its crucial role for people living in West Java Province despite some pollution issues recently. The research was conducted from January to May 2016 during rainy season. The aim of it was to assess water quality of Lake Cisanti and reveal that Trematodes cearcariae could be used as bio indicator of organic pollution. From identification results, there were 31 morphospecies of macrozoobenthos from seven classes found in Lake Cisanti. Melanoides tuberculata had the highest total density (188 ind/m2). It implied that organic matter due to open defecation polluted Lake Cisanti. Based on the value of CCMEWQI, H', and FBI, it can be concluded that water quality of Lake Cisanti comprehensively was unpolluted during January-May 2016. Water conductivity and organic carbon of sediment had the strongest correlation with macrozoobenthos biodiversity in Lake Cisanti. In order to comprehensively understand the main factors of physical and chemical parameters of water and sediment parameters influencing macrozoobenthos biodiversity, Principal Component Analysis (PCA) was required. Based on PCA results, there were two main factors of water parameters, F1 (consist of turbidity and COD) and F2 (consist of temperature and conductivity). Those could explain $73.268 \%$ variance of all water parameters. Furthermore, the overall prevalence of Trematode cercariae in Molluscs was about 5.49\%. There was significant and strong correlation between prevalence of Trematodes cercariae and fecal coliform concentration based on Spearman correlation analysis. It implied that Trematodes cercariae could be considered as a bio indicator of organic pollution, even though a further research is needed to test it in various aquatic ecosystems, both laboratory (man-made ecosystem) and natural ecosystem scales.
\end{abstract}

Key words: Lake Cisanti, bio indicator, macrozoobenthos, Molluscs, Trematodes cercariae

\section{INTRODUCTION}

Water quality assessment is an early stage of water quality management program, and the final goal is the water body conservation that meets the criteria of raw water health, aesthetic criteria, as well as ecological criteria, thus it is safe for aquatic life (Saraswati et al., 2012). Lake Cisanti is the upstream of Citarum River. It is the main water supplier for Tarumajaya village, tourism place, irrigation for agriculture and traditional fisheries. Lake Cisanti was an eutrophic lake and the water quality was decreasing due to excessive pollutants entering Cikawadukan inlet from bathing activity as one of

* To whom correspondence should be addressed. ritual for local people and domestic tourists, and fertilizer from planting and agricultural areas surrounding Lake Cisanti (Sulastri et al., 2010; Hasan et al., 2013). Based on its allocation, Lake Cisanti was classified as water class II according to Indonesian Government Regulation No. 82/2001. In order to maintain it, Environmental Protection Institution of Bandung District and Perum Jasa Tirta II in outlet areas conducted water quality monitoring in Lake Cisanti regularly. If monitoring is conducted only in the outlet area, the potential pollution source in inlet areas cannot be detected. Water quality monitoring can be conducted by aquatic organism studies. Aquatic organisms can reveal temporary and cumulative pollution effects and habitat change (Chazanah et al., 2015). 
Macrozoobenthos is used as water quality indicator because they have low mobility, sensitive to some pollutants, and have adequate size for field examination, storage and transportation. They also are easy to collect, not hard to be found in every kind of water body and have various life cycles, from weeks to years (Chazanah et al., 2015; Pong-Masak \& Pirzan, 2006).

The most abundant macrozoobenthos in the outlet of Lake Cisanti was Melanoides tuberculata (Iriany, 2014). It was the indicator for organic pollution due to open defecation (Giovanelli et al., 2005), because Melanoides tuberculata was more tolerant to some abiotic stressors, such as high temperature, malathion, cadmiun and drought. Melanoides tuberculata was more tolerant in polluted habitats (Weir \& Salice, 2012). It is one of intermediate host of Trematodes. Trematodes also infect other kinds of freshwater snails, such as Biomphalaria glabrata (Giovanelli et al., 2005), Lymnea stagnalis and Radix balthica (Voutilainen et al., 2009). The transmission route of Trematodes in water and aquatic organisms is related to the excreta (feces and urine) of human and cattle infected by Trematodes (Bourne, 1984). The presence of it in Molluscs could be an indicator for organic pollution from excreta waste. Therefore, it was needed to study about macrozoobenthos community to assess the water quality of Lake Cisanti. Meanwhile, trematodes examination in Molluscs was conducted to reveal the pollution potential from feces or urine of human or Vertebrates infected by Trematodes.

\section{MATERIALS AND METHODS}

\section{Sampling location}

The sampling was conducted in Lake Cisanti $\left(7^{\circ} 12^{\prime} 28.5^{\prime} \mathrm{S}\right.$ and $\left.107^{\circ} 39^{\prime} 34.0^{\prime \prime} \mathrm{E}\right)$. It is located administratively in Tarumajaya Village, Kertasari Sub-district, Bandung District, West Java Province. The sampling points were located in three parts, inlet, midlet and outlet of Lake Cisanti. The samples were taken four times from January to May 2016. Macrozoobenthos samples were taken from sediment samples, while Trematodes cercariaes were extracted from macrozoobenthos bodies.

\section{Sampling methods}

Macrozoobenthos sampling was conducted by taking sediment samples using Eckman grab and surbur net. Sediment samples were corned using formalin $4 \%$. Sediment samples were sieved using sieve no. 200, then it was washed using freshwater and the clean benthos were corned again using 70\% alcohol (Oktarina \& Syamsudin, 2015).

\section{Identification methods}

Macrozoobenthos identification was conducted using morphospecies method. Mollusc samples (Gastropoda and Bivalvia) were separated from other macrozoobenthos samples and kept in plastics. The plastics were filled with water from lake without any preservation to keep them alive. Trematodes examination used shedding method. The Molluscs were separated individually and kept for 24 hours in petri dish, which were filled with $5 \mathrm{~mL}$ of dechlorination water. The presence of Trematodes in dechlorination water was examined under microscope. Another method to examine the Trematodes was crushing method and was conducted by crushing the Molluscs (Mohammad, 2015). Cercariae was examined under $10-40 \times$ microscope magnification. The cercariae identification was limited to the determination of cercariae type (Frandsen \& Christensen, 1984).

\section{Water quality status}

The water quality status was determined using Canadian Council of Ministers of the Environment Water Quality Index (CCME-WQI) (Saraswati et al., 2012), Shannon-Wiener index (H') (Fachrul, 2007), and Family Biotic Index (FBI) (Mandaville, 2002). Furthermore, Pearson and Spearman correlation analysis was used to analyze the influence of each physic-chemical parameter of water and sediment to the macrozoobenthos biodiversity and prevalence of Trematodes ceracariae in freshwater Molluscs. Meanwhile, Principal Component Analysis (PCA) was used to analyze the main factors from physicchemical parameters of water and sediment, and their relation to the macrozoobenthos biodiversity.

\section{RESULTS AND DISCUSSION}

The average of all water parameters in seven sampling points met the regulation (water class II based on Indonesian Government Regulation No. $82 / 2001$ ), except TSS, COD and fecal coliform from water samples inlet 4 and COD concentration in the outlet. Inlet 4 had the most abundant macrophyte of all sampling point. The shilting has occurred up to 25 meters to the middle of Lake Cisanti. Potential pollutant sources were vegetable plantation and extensive fishponds in the flow of the Cisanti springs located in the inlet 4 (Figure 1).

The soil leaching containing fertilizers and pesticides by runoff, as well as fish feed residues provides organic and inorganic nutrient input. The nutrient input caused eutrophication of water bodies and ultimately reduced the water capacity of lake due to silting. The law enforcement is required regarding land use in the catchment area of Lake 


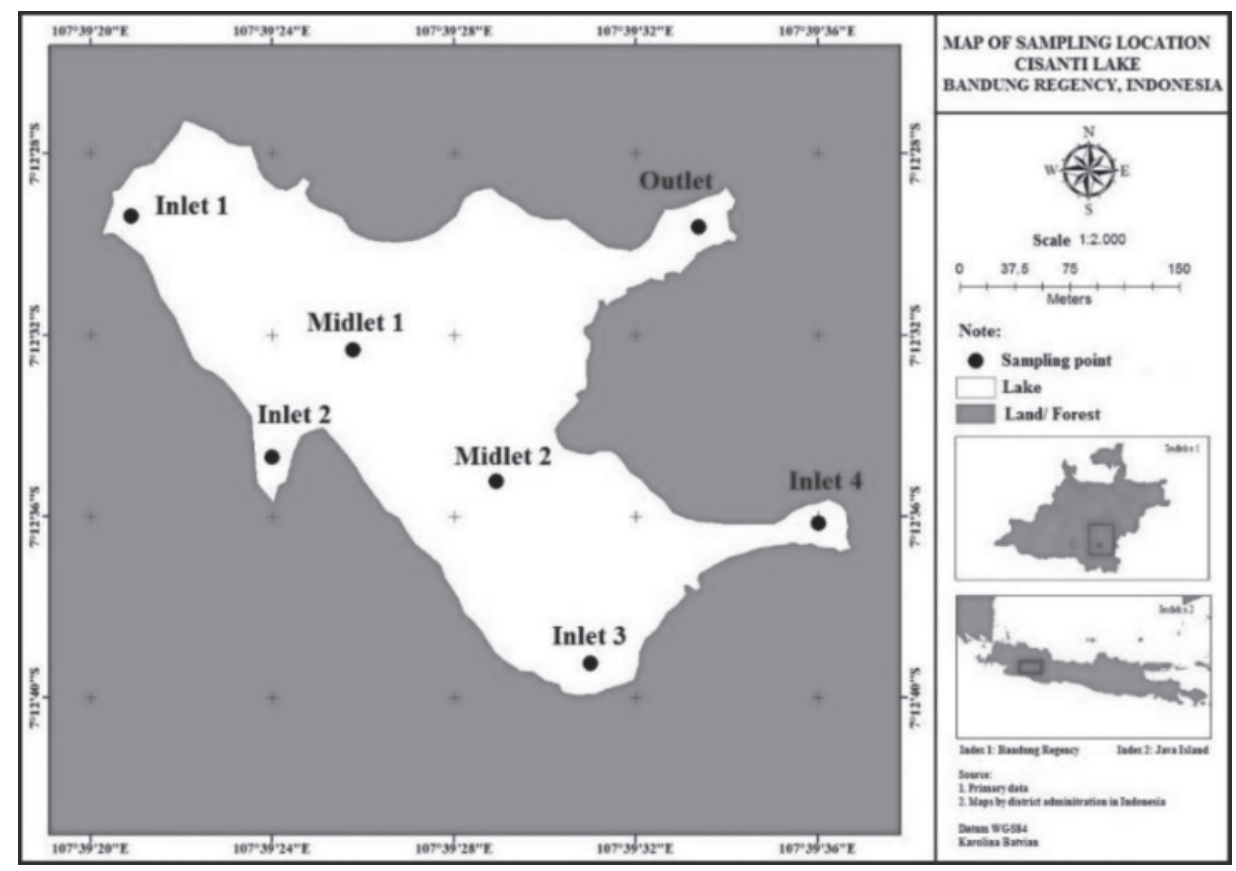

Fig. 1. Sampling location (Source: primary data, 2016; Google ${ }^{\circledR}, 2016$ ).

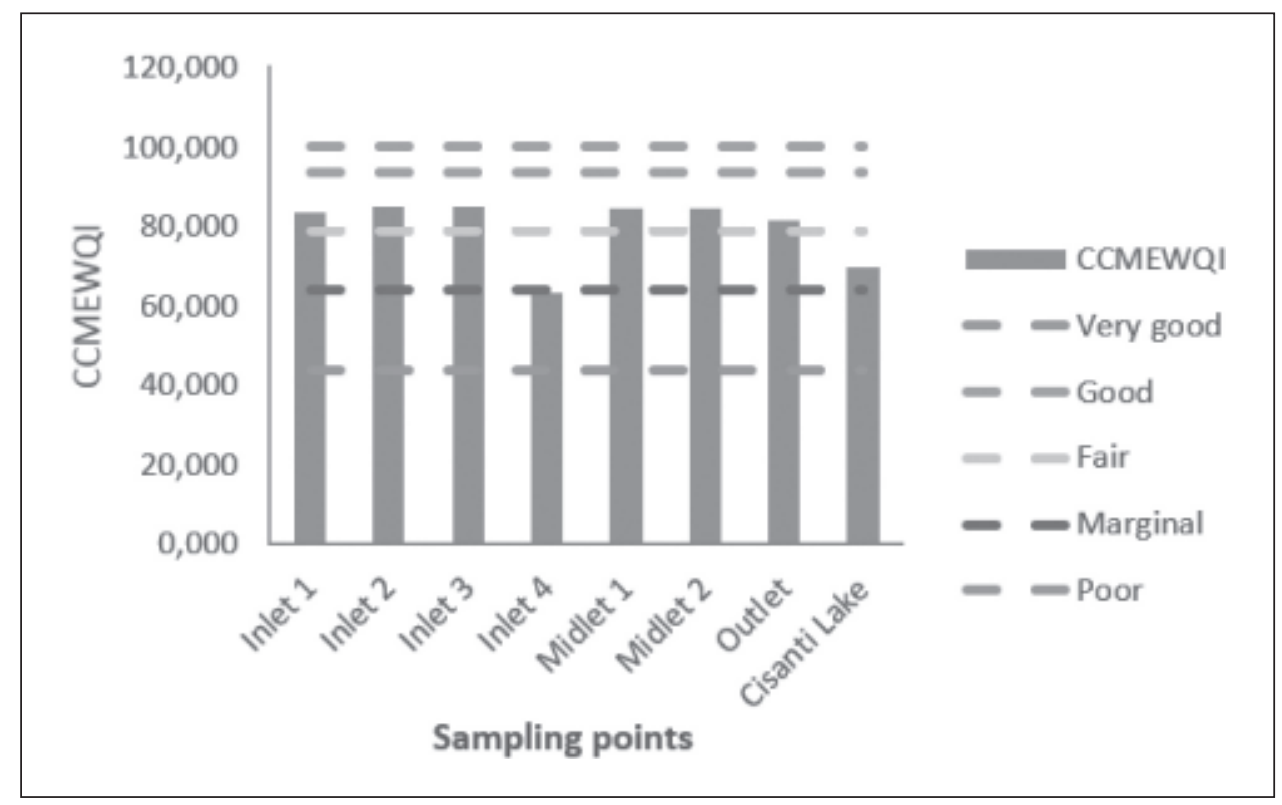

Fig. 2. CCME-WQI value and its interpretation to the water quality.

Cisanti (Bandung District Regulation No. 3/2008) to prevent the deterioration of water quality. The plantations in catchment area of Lake Cisanti were about 23.4 hectares. The erosion rate of the catchment area in Lake Cisanti is a natural process, which cannot be avoided, and land use change will increase the erosion rate. A mix of crop rotation on the farmlands can minimize the rate of erosion (Perdana \& Sudjono, 2006).

Water from outlet of Lake Cisanti can be used as raw water for drinking water, but some treatments were needed to decrease COD concentration in order to meet the quality standard for water class I based on Indonesian Government Regulation No. $82 / 2001$. Water quality of Lake Cisanti was fair based on the value of CCMEWQI (Figure 2), and it was unpolluted based on H' (Figure 3 ) and FBI (Figure 4). Therefore, water quality of Lake Cisanti comprehensively was categorized as unpolluted during January-May 2016.

Based on identification results, there were 31 morphospecies of macrozoobenthos from seven 


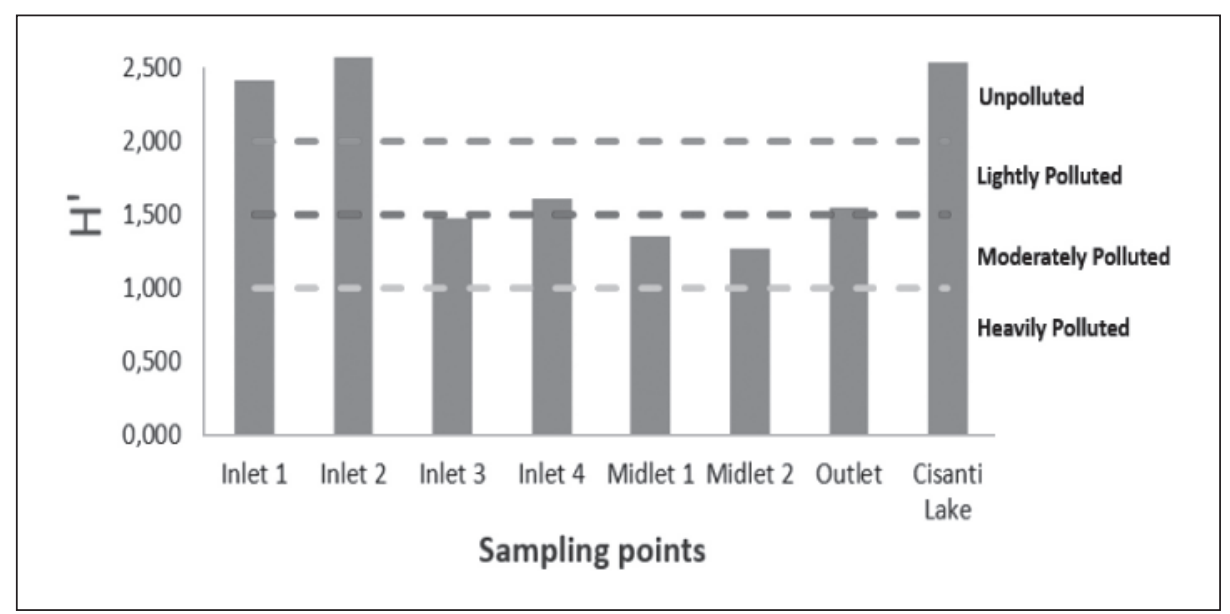

Fig. 3. H' value and its interpretation to the water quality.

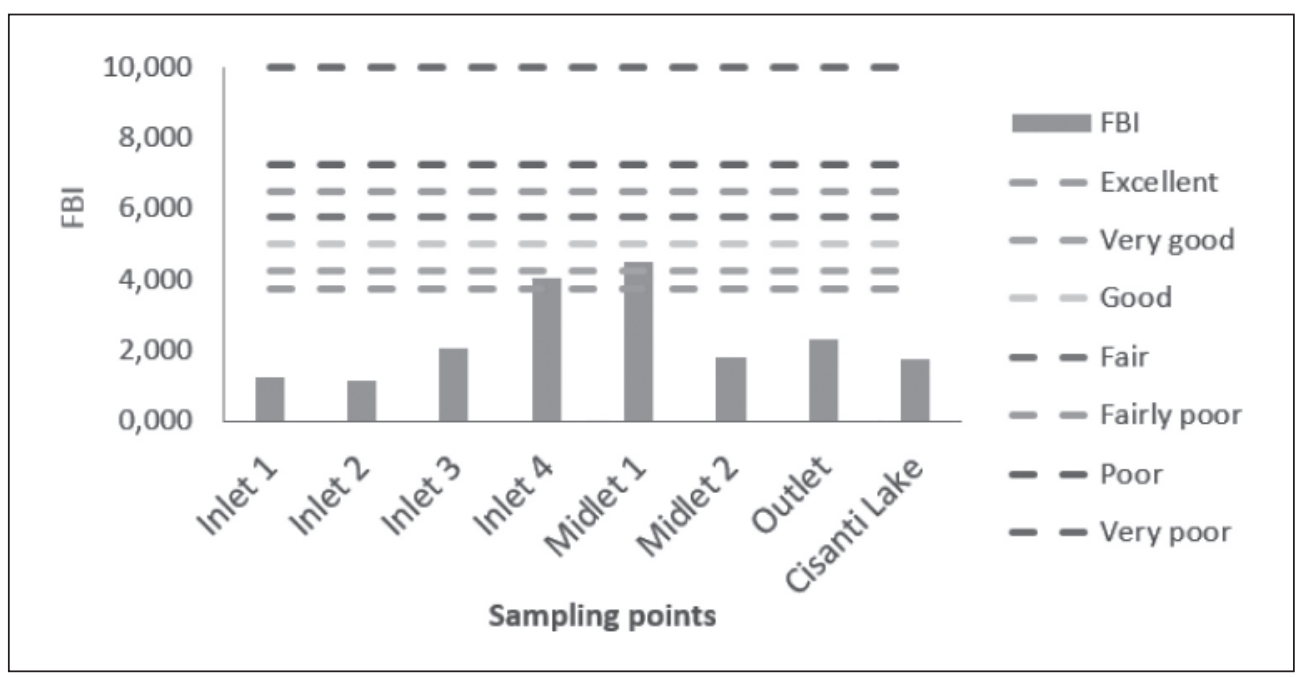

Fig. 4. FBI value and its interpretation to the water quality.

classes. Gastropod had the highest density $(73.92 \%$ of total density) and could be found in all sampling points (Figure 5). It had the highest abundance because it can live in muddy and sandy substrate, attach to rocky substrate (Oktarina \& Syamsudin, 2015) and aquatic vegetation. Furthermore, macrozoobenthos that had the highest total density were Melanoides tuberculata $\left(188 \mathrm{ind} / \mathrm{m}^{2}\right)$, Lumbricus $\mathrm{sp}$. (88.16 ind $\left./ \mathrm{m}^{2}\right)$ and Brotia $\mathrm{sp.} 1\left(58.33 \mathrm{ind} / \mathrm{m}^{2}\right)$.

The water conductivity and organic carbon of sediment were parameters having the strongest correlation with macrozoobenthos in Lake Cisanti. The biodiversity of macrozoobentos in Lake Cisanti had linear correlation with water conductivity, where the average range of water conductivity in Lake Cisanti was $115.45-223.13 \mu \mathrm{S} / \mathrm{cm}$. In water bodies having water conductivity $150-450 \mu \mathrm{S} / \mathrm{cm}$, aquatic organisms can live well (Lonkar et al., 2015). The positive correlation between water conductivity and macrozoobenthos biodiversity possibly was caused by the highest water conductivity at Lake Cisanti, which was lower than the limit of water conductivity in the upstream. The macrozoobenthos biodiversity in Lake Cisanti had negative correlation with the amount of organic carbon of sediment. A small portion of macrozoobenthos communities in tapering habitat found in places with high organic content of the soil, nitrate and ammonium. Macro benthos having nature digger eaters tend to live in the sediment deposits of mud and soft sediments, which are rich of organic matters (Oktarina \& Syamsudin, 2015). Furthermore, in the inlet 4 , midlet 1 and midlet 2 (Figure 1), Oligochaeta was the most abundant class. Oligochaeta prefers organic-rich environment and can dominate a polluted environment (Lonkar et al., 2015). The simple linear regression equation between biodiversity macrozoobenthos and the content of organic carbon in the sediments is $\mathrm{Y}=2.262-$ $0.089 \mathrm{X}$; with $\mathrm{R}^{2}=0.810$, which meant $81 \%$ of the 


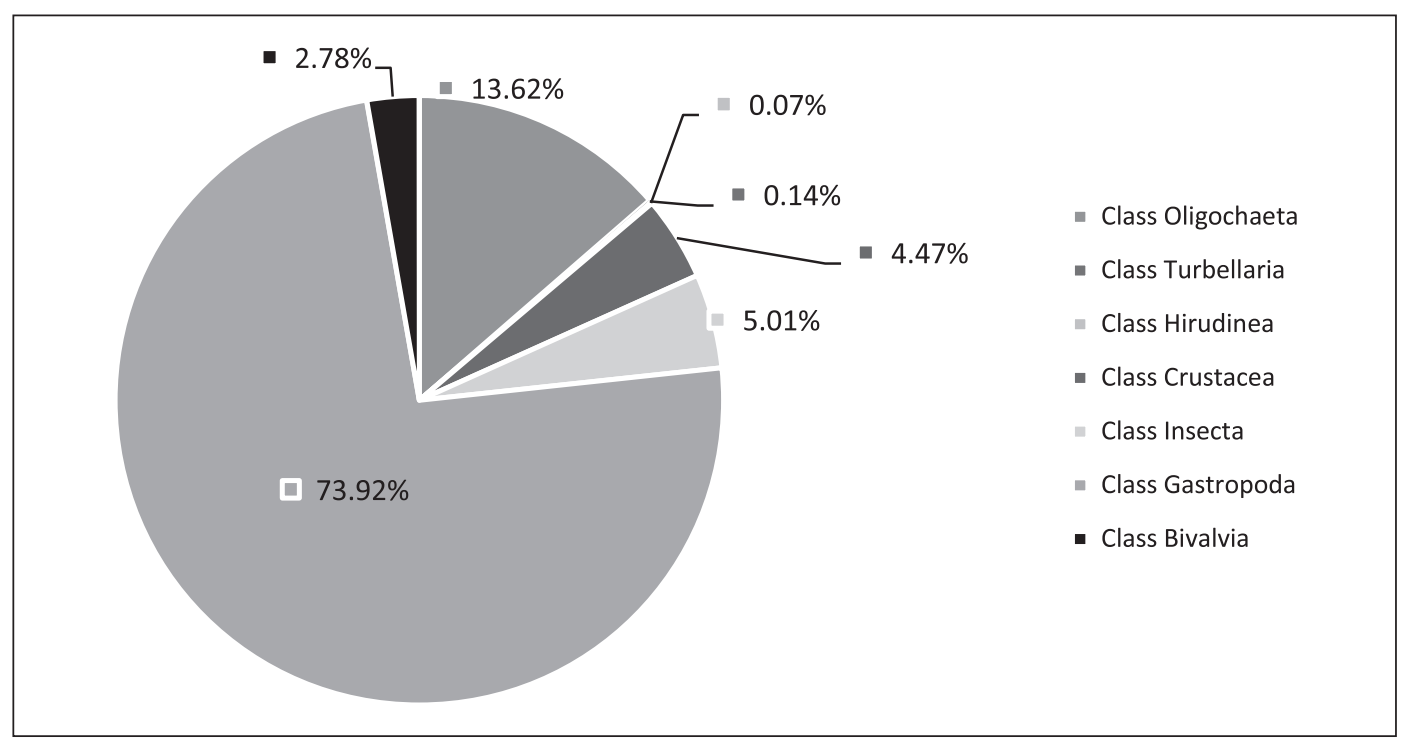

Fig. 5. Macrozoobenthos composition in Lake Cisanti.

variation of macrozoobenthos biodiversity was caused by the organic carbon content in the sediment, while the remaining was caused by other parameters.

The PCA results formed two main factors from water parameters, F1 and F2. F1 consisted of turbidity and COD. Erosion and nutrient input from the area around the inlet contributes to turbidity and COD. F2 consisted of temperature and conductivity. By its nature as a thermal buffering, water is suitable habitat for aquatic organisms, which are cold-blooded (adjust the temperature to the ambient temperature). Therefore, temperature and conductivity have a very close relationship and are an important parameter to assess water quality. F1 and F2 explained 73.268\% variance of all water parameters. Based on multiple linear regression analysis result, the relationship between macrozoobenthos biodiversity and the two main factors was $\mathrm{Y}=1.512-0.028 \mathrm{~F} 1+0.482 \mathrm{~F} 2$. Variance of macrozoobenthos biodiversity could be explained by $\mathrm{F} 1$ and $\mathrm{F} 2$ as well as $49.9 \%$. F1 did not influence significantly to the macrozoobenthos biodiversity.

The overall prevalence of Trematodes cercariae in Lake Cisanti was $5.49 \%$. The cercariae types were monostome cercariae (Figure 6) and virgulate xiphidiocercariae (Figure 7). Fecal coliform concentration in all sampling point met the water quality standard, except at inlet 4 (Figure 1). Based on Spearman correlation analysis, there was strong and significant relationship between prevalence of Trematodes cercariae and fecal coliform concentration. It implied that Trematodes cercariae could be used as indicator of organic waste pollution. Further studies are needed to determine usefulness of Trematodes cercariae as bioindicator

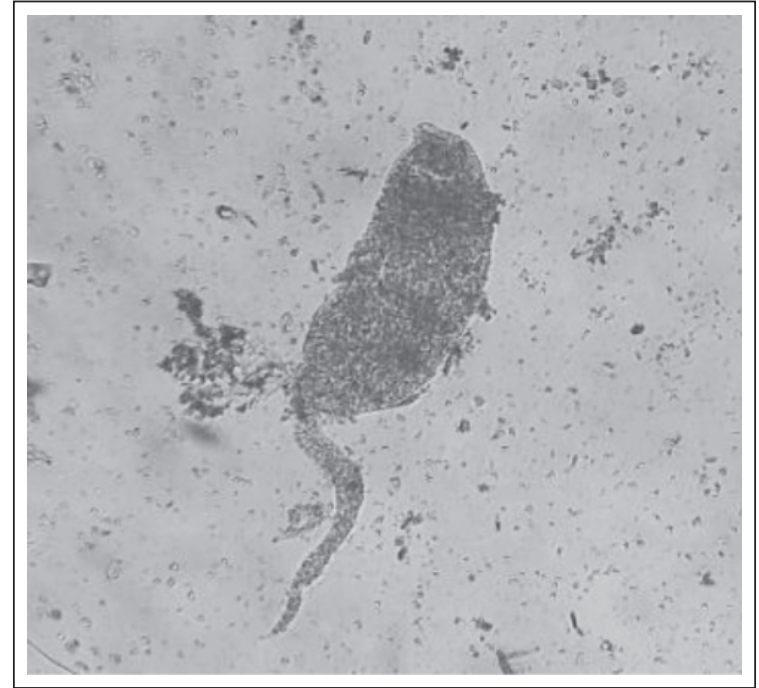

Fig. 6. Monostome cercariae.

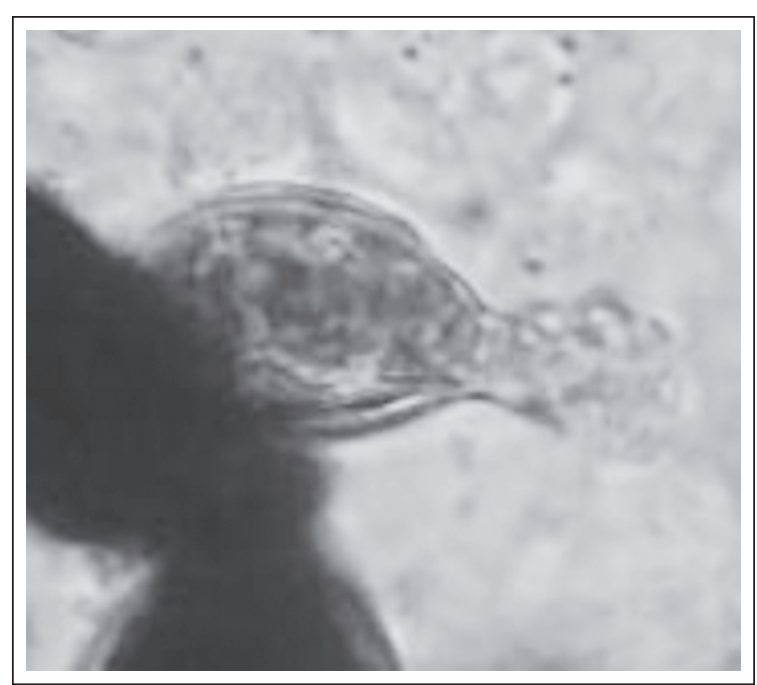

Fig. 7. Virgulate xiphidiocercariae. 
in various water qualities, which is related to the human activities and seasonal variance. The prevalence of Trematodes cercariae in Molluscs at Lake Cisanti was relatively low, but it is needed to prevent the increase of distribution area and its prevalence percentage. To decrease the incidence of infectious diseases due to Trematodes, it is suggested to boil the water and cook the scallops and conch meat before consuming them.

It can be concluded that water quality of Lake Cisanti comprehensively was unpolluted during January-May 2016 based on the value of CCMEWQI, H' and FBI. However, the high abundance of Melanoides tuberculata implied that Lake Cisanti was potentially polluted by organic pollution due to open defecation. Moreover, the presence of Trematodes cercariae in Molluscs implied that there was potential water contamination due to excreta of human or Vertebrates infected by Trematodes. The strong and significant relationship between prevalence of Trematodes cercariae and fecal coliform concentration implied that Trematodes cercariae could be considered as bioindicator of organic pollution, especially due to excreta contamination. Further studies are needed to determine if Trematodes cercariae can be used as bioindicator in various water qualities related to the human activities and seasonal variance. It is also needed to test it in various aquatic ecosystems, both in laboratory (man-made ecosystem) and natural ecosystem scales.

\section{ACKNOWLEDGMENTS}

This work was supported by Indonesian Directorate General of Higher Education (DIKTI), Water Quality Laboratory (Department of Environmental Engineering, Faculty of Civil and Environmental Engineering, Institut Teknologi Bandung), and Microbiology and Parasitology Laboratory (Medical School of Universitas Padjajaran). Special thanks to Karolina Batvian as a research partner at Lake Cisanti.

\section{REFERENCES}

Bourne, P.G. (1984). Water and Sanitation: Economic and Sociological Perspectives, Academic Press, Inc., Washington DC.

Chazanah, N., Muntalif, B.S., Suantika, G. \& Sudjono, P. (2015). Determination River Water Quality with Bioassessment Using Benthic Macroinvertebrates (Case Study: Citarum Upstream, West Java, Indonesia), The $5^{\text {th }}$ Environmental Technology and Management Conference "Green Technology towards
Sustainable Environment, ISBN: 978-97998278-5-2.

Fachrul, F.M., Dr. (2007). Metode Sampling Bioekologi. Jakarta: Bumi Aksara.

Frandsen, F. \& Christensen, N.O. (1984). An Introductory Guide to The Identification of Cercariae From African Freshwater Snails With Special Reference to Cercariae of Trematode Species of Medical and Veterinary Importance, Acta Tropica, 41: 181-202.

Giovanelli, A., Silva, C.L.P.A.C., Leal, G.B.E. \& Baptista, D.F. (2005). Habitat Preference of Freshwater Snails in Relation to Environmental Factors and The Presence of The Competitor Snail Melanoides tuberculatus (Muller, 1774), Mem Inst Oswaldo Cruz, 100(2): 169-176.

Hasan, Z., Syawalludin, I.N. \& Lili, W. (2013). Struktur Komunitas Plankton di Situ Cisanti Kabupaten Bandung, Jawa Barat, Jurnal Akuatika, 4(1): 80-88, ISSN 0853-2523.

Iriany, M. (2014). Kualitas Sungai Citarum Hulu Berdasarkan Keanekaragaman Makrozoobentos dan Toksisitas Terhadap Allium cepa (Bawang Merah), Thesis from Department of Environmental Engineering, Institut Teknologi Bandung.

Lonkar, S.S., Kedar, G.T. \& Tijare, R.V. (2015). Assessment of Trophic Status of Ambazari Lake, Nagpur, India With Emphasis to Macrozoobenthos as Bioindicator, Int. J. of Life Science, 3(1): 49-54.

Mandaville, S.M. (2002). Benthic Macroinvertebtares in Freshwater - Taxa Tolerances Value, Metrics, and Protocols, Soil and Water Conservation Society of Metro Halifax.

Mohammad, M.K. (2015). The Parasitic Infection of the Freshwater Snails Collected in Central Iraq, International Journal of Current Microbiology and Applied Science, 4(3): 47-55.

Oktarina, A. \& Syamsudin, T.S. (2015). Keanekaragaman dan Distribusi Makrozoobentos di Perairan Lotik dan Lentik Kawasan Kampus Institut Teknologi Bandung, Jatinangor Sumedang, Jawa Barat, Pros Sem Nas Masy Biodiv Indon, 1(2): 227-235.

Perdana, A. \& Sudjono, P. (2006). Pengaruh Tataguna Lahan Terhadap Laju Erosi di Daerah Tangkapan Waduk Cisanti, Jurnal Teknik Lingkungan Edisi Khusus, ISSN 0854-1957.

Pong-Masak, P.R. \& Pirzan, A.M. (2006). Komunitas Makrozoobentos Pada Kawasan Budidaya Tambak di Pesisir Malakosa Parigi-Moutong, Sulawesi Tengah, Biodiversitas, 7(4): 354-360. ISSN: 1412-033X M Iriany 2014 Kualitas Sungai Citarum Hulu Berdasarkan Keanekaragaman Makrozoobentos dan Toksisitas Terhadap Allium cepa (Bawang Merah) (Bandung: Institut Teknologi Bandung). 
Saraswati, S.P., Sunyoto, Kironoto, B.A. \& Hadisusanto, S. (2014). Kajian Bentuk dan Sensitivitas Rumus Indeks PI, STORET, CCME Untuk Penentuan Status Mutu Perairan Sungai Tropis di Indonesia, Jurnal Manusia dan Lingkungan, 21(2): 129-142.

Sulastri, Suryono, T., Sudarso, Y. \& Nomosatriyo, S. (2010). Pengembangan Kriteria Status Ekologis Danau-Danau Kecil di Pulau Jawa, Limnotek, 17(1): $58-70$.
Voutilainen, A., Ooik, P.V., Puurtinen, M., Kortet, R. \& Taskinen, J. (2009). Relationship Between Prevalence of Trematode Parasite Diplostomum sp. and Population Density of Its Snail Host Lymnea stagnalis in Lakes and Ponds in Finland, Aquat Ecol, 43: 351-357.

Weir, S.M. \& Salice, C.J. (2012): High Tolerance to Abiotic Stressor and Invasion Success of The Slow Growing Freshwater Snail, Melanoides tuberculatus, Biol Invasions, 14: 385-394. 
